\title{
Antidiabetic and antiradical activities of plants from Venezuelan Amazon
}

\author{
María Rodríguez, ${ }^{* 1}$ Masahisa Hasegawa, ${ }^{1}$ Freddy González-Mújica, ${ }^{2}$ Norma Motta, ${ }^{2}$ Anibal \\ Castillo, ${ }^{3}$ Jimmy Castillo, ${ }^{4}$ Elsa Zea, ${ }^{1}$ Kiby Mora, ${ }^{1}$ Luis Sousa, ${ }^{1}$ Alejandro González, ${ }^{4}$ \\ David Camejo ${ }^{4}$
}

${ }^{1}$ Laboratorio de Productos Naturales, Escuela de Química, Facultad de Ciencias, Universidad Central de Venezuela, Apartado Postal 47102, Caracas 1020A, Venezuela,

${ }^{2}$ Sección de Bioquímica Médica, Instituto de Medicina Experimental, Facultad de Medicina, Universidad Central de Venezuela, Apartado Postal 50587, Caracas 1040A, Venezuela,

${ }^{3}$ Centro de Botánica Tropical, Escuela de Química, Facultad de Ciencias, Universidad Central de Venezuela, Apartado Postal 47102, Caracas 1020A, Venezuela,

${ }^{4}$ Laboratorio de Espectroscopia Láser, Escuela de Química, Facultad de Ciencias, Universidad Central de Venezuela, Apartado Postal 47102, Caracas 1020A, Venezuela

\begin{abstract}
RESUMO: "Atividades antidiabética e anti-radicalar de plantas da Amazônia venezuelana". Os extratos aquoso e etanólico derivados de doze espécies coletadas na Amazônia venezuelana foram testados quanto à atividade antioxidante utilizando um radical DPPH e o efeito inibitório sobre a hidrólise de glicose-6-fosfato nos microssomas intactos e perturbados. Sem exceção, todos os extratos inibiram, em maior ou menor grau, a atividade enzimática microssomal de G6-Pase, resultando em maior inibição nos microssomas intactos do que nos perturbados. Efeitos marcantes foram observados para os extratos aquoso e etanólico de: Tontelea ovalifolia, Gustavia pulchra, Phthirusa verruculosa, Phthirusa castillana, Psittacanthus acimarius, Tetrapterys styloptyera e Vismia japurensis. Os extratos etanólicos foram seqüestradores do radical DPPH mais eficazes do que os correspondentes extratos aquosos em todos os casos. O extrato etanólico de Endlicheria anomala e o extrato aquoso de Phthirusa verruculosa exibiram as melhores $\mathrm{CI}_{50}$ com 100 e 250.0 ppm, respectivamente. Os valores de Kobs calculados para os extratos alcoólicos foram mais baixos do que os dos extratos aquosos das mesmas espécies, exceto Psittacanthus acimarius. Estes resultados poderiam estar relacionados a diferentes concentrações, ou mais provavelmente a diferentes composições de princípios ativos em ambos extratos.
\end{abstract}

Unitermos: Plantas amazônicas, atividade antidiabética, atividade anti-radicalar, glicose-6fosfatase.

\begin{abstract}
The aqueous and ethanol extracts derived from twelve plant species collected in the Venezuelan Amazon have been tested for antioxidant activity using a DPPH radical and inhibitory effect on the hydrolysis of glucose-6-phosphate in intact and disrupted microsomes. Without exception, all the extracts inhibited, to a greater or lesser degree, microsomal G-6-Pase enzymatic activity, resulting in greater inhibition on intact microsomes than on disrupted ones. Marked effects were observed for aqueous and ethanol extracts of: Tontelea ovalifolia, Gustavia pulchra, Phthirusa verruculosa, Phthirusa castillana, Psittacanthus acimarius, Tetrapterys styloptyera and Vismia japurensis. Ethanol extracts were more effective DPPH radical scavengers than the corresponding aqueous extracts in all the cases. The ethanol extract of Endlicheria anomala and the aqueous extract of Phthirusa verruculosa, showed the best $\mathrm{IC}_{50}$ with 100 and $250.0 \mathrm{ppm}$, respectively. The Kobs calculated for the alcoholic extracts were lower than those of the aqueous extracts for the same species, except Psittacanthus acimarius. These results could be related to different concentrations, or more likely different compositions of active principles in both extracts.
\end{abstract}

Keywords: Amazonian plants, antidiabetic activity, antiradical activity, glucose-6-phosphatase.

\section{INTRODUCTION}

Free radicals (ROS) are atoms or atomic groups containing unpaired electrons that indiscriminately pick up electrons from other species, converting those into secondary free radicals, and thus setting up a chain reaction that can cause substantial biological damage (e.g. lipids, proteins, DNA) leading to many chronic 
diseases like cancer, Parkinson, Alzheimer, diabetes, and aging (Halliwell, 1994; Finkel and Holbrook, 2000).

Oxygen free radicals can initiate peroxidation of lipids, which in turn stimulates glycation of protein, inactivation of enzymes and alteration in the structure and function of collagen basement and other membranes, and play a role in the long term complication of diabetes (Collier et al., 1990; Boynes, 1991).

Plants may be a source of a wide variety of free radical scavenging molecules, such as phenolic compounds (e.g. flavonoids, coumarins, quinones, etc), nitrogen compounds (alkaloids), terpenoids and some other metabolites (Larson, 1988; Delazar et al., 2006). Finding new natural sources of antioxidant compounds with potential antiradical activity can be useful to future therapy against diabetes mellitus (Mc Cune and Johns, 2002; Sabu and Kuttan, 2002; Tiwari and Rao, 2002; Silva et al., 2005).

The antioxidant activity was assessed using the 1,1-diphenyl-2-picryl-hydrazyl (DPPH) radical which is widely used for quickly determination of polyphenols antioxidant capacity (Mc Cune and Johns, 2002; Silva et al., 2005; Vicentino and Menezes, 2007). Generally, the kinetics of $\mathrm{H}$ atom transfer is not evaluated, however could be even more important than the ability of antioxidants to transfer labile $\mathrm{H}$ atom to this radical (Koleva et al., 2001). Several studies of free radical scavenging reaction reported kinetic data like $\mathrm{K}_{\mathrm{obs}}$ to estimate the "efficiency" or capacity of antioxidants present in plant extracts (Naik et al., 2004; and 2006).

On the other hand, previous results of the biological screening, referred to brine shrimp lethality test, cardiovascular and glucose-6-phosphatase (G-6Pase) assays of 17 plants belonging to 13 families from the Amazon region was reported (Jiménez et al., 2001). It is known that the G-6-Pase enzyme complex plays a critical role in blood glucose homeostasis and in type II diabetes (Westergaard and Madsen, 2001).

In this paper we present glucose-6-phosphatase and DPPH based antioxidant assay from the ethanol and aqueous extracts of 13 Amazonian species. To our best knowledge, there are few data on mentioned activities of these plants. In the DPPH assay, we report the kinetic data and $\%$ inhibition. We also report preliminary phytochemical analyses of these extracts in order to find out possible metabolite and activity relationship.

\section{MATERIAL AND METHODS}

\section{Plant collection}

The specimens were collected around the Cataniapo River, $8 \mathrm{~km}$ southeast from Puerto Ayachucho City, capital of the State of Amazonas, cartographically situated between $5^{\circ} 36^{\prime}-5^{\circ} 39^{\prime} \mathrm{N}$ and $67^{\circ} 6^{\prime}-67^{\circ} 29^{\prime} \mathrm{W}$, with an altitude of 80-250 m above sea-level. Voucher specimens are deposited in the National Herbarium of

Venezuela (VEN) and the Ambiental Ministry Herbarium at Puerto Ayachucho City (TFAV). Complete plant names, families and authority are indicated in Table 1.

\section{Extract preparation}

The collected fresh leaves and twigs from each plant were kept in cloth bags until the end of every day field work, then chopped into pieces, filled a glass bottle of $500 \mathrm{~mL}$ capacity with $95 \%$ ethanol, and stored for two months at room temperature to accomplish exhaustive extraction. Then, the ethanol extract was decanted and concentrated in vacuum to dryness. The dry ethanol extract was treated with distilled water and the water soluble part was freeze-dried. The preparation thus obtained, named aqueous extract, was kept in a glass vial at $-20{ }^{\circ} \mathrm{C}$ until biological assays were performed. The residual water-insoluble part is named ethanol extract in this work. These extract preparation procedures were not controlled quantitatively.

\section{Phytochemical screening}

Preliminary phytochemical analysis was carried out using thin layer chromatography. The TLC analysis was performed on silica gel plates developed with a mixture of dichloromethane-methanol (8:2 and $9.75: 0.25)$. Spots were revealed by the following sprayreagents: Dragendorff reagent for alkaloids as orange spots; $5 \%$ methanol solution of saturated ceric sulphate in concentrate sulphuric acid for detection of terpenes and flavonoids, the presence of triterpenoids suggested by violet spots and flavonoids by yellow spots (Stahl, 1969; Bilia et al., 1996); Phosphomolybdic acid for lipids, fatty acids, steroids and essential oils (Stahl, 1969) with black or dark green spots and the universal Godin reagent, the observation of violet or blue and red spots is indicative of the presence of monoterpenoids including essential oils. Detection of polyphenols e.g. flavonoids, xanthones, naphthoquinones were suggested by yellow spots and secoiridoids by brown spots with the same Godin reagent (Wagner et al., 1984).

\section{Biological assays}

\section{Glucose-6-phosphatase assay}

Liver microsomes were purified as described from rats fasted overnight (Marcucci et al., 1983). Protein concentration was estimated using the modification of the Lowry method described by Markwell et al. (1978). The G-6-Pase assay of intact and disrupted microsomes using Histone II A (Sigma Chemical Co. USA) was performed following Burchell et al. (1988). In brief, the assay was carried out with $40 \mu \mathrm{L}, 5 \mathrm{mM}$ of G-6-P as substrate in the absence (control) or in the presence of $40 \mu \mathrm{L}, 520 \mathrm{ppm}$, of aqueous or alcoholic extracts in 10 
$\%$ DMSO and finally $20 \mu \mathrm{L}(20-30 \mu \mathrm{g})$ of microsomal protein to give a $100 \mu \mathrm{L}$ final volume. The reaction was taken in a water bath at $30{ }^{\circ} \mathrm{C}$ for $10 \mathrm{~min}$. It was stopped by adding $0.9 \mathrm{~mL}$ of $0.28 \%$ ammonium molybdate, $1.11 \%$ sodium dodecyl sulphate and $1.11 \%$ ascorbic acid in $0.33 \mathrm{M}$ sulphuric acid. The mixture was incubated at $47^{\circ} \mathrm{C}$ for $20 \mathrm{~min}$ and the absorption of colored complex was recorded at $820 \mathrm{~nm}$. Phloridzin $(250 \mathrm{ppm})$ was used as a positive control. The activity is expressed as $\mu \mathrm{mol}$ phosphate released $/ \mathrm{h} / \mathrm{mg}$ of protein and each value represents the average of 5 separate experiments \pm standard deviation. The results are also expressed as the percentage of inhibition in comparison with control.

\section{Antiradical activity}

Radical scavengers detection on TLC plates was performed using the DPPH method (Cuendet et al., 1997), being positive those compounds which exhibited yellow spots against a purple DPPH background.

Quantitative evaluation of radical scavenging abilities of the aqueous and ethanol extracts was carried out by uv spectrophotometric measurement using quercetin as reference compound. DPPH has a purple colour $(\lambda \quad 515-517 \mathrm{~nm})$ and becomes colorless in the presence of a substance capable of donating an electron. Absorbance decrease of freshly prepared 60 $\mu \mathrm{M}$ solution of DPPH in methanol in presence and absence of different concentrations of plant extracts was continuously recorded at $515 \mathrm{~nm}$ at $25^{\circ} \mathrm{C}$ every $0.5 \mathrm{~s}$. All the experiments were carried out in triplicate. The rate constants data were obtained to 1-5 min using an extract concentration corresponding to a total consumption of DPPH (Naik et al., 2004 and 2006; Andrade et al., 2007;
Rocha et al., 2007).

\section{RESULTS}

Tables 1, 2, and 3 present the results of a preliminary phytochemical analysis, effects on the enzymatic activity of G-6-Pase and evaluation of the antiradical activity of 23 extracts derived from 12 plant species collected in the Venezuelan Amazon.

\section{Phytochemical screening}

Table 1 presents the preliminary phytochemical analysis of the extracts using thin layer chromatography. Almost all the ethanol extracts showed possible presence of triterpenoids and essential oils as blue-violet and red spots by ceric sulphate and Godin reagents. The majority of the aqueous and ethanol extracts showed the presence of alkaloids using the Dragendorff reagent. Secoiridoids were detected in the aqueous extracts of half of the plants examined, but less in the alcoholic extracts. Polyphenolic compounds other than flavonoids were observed only in $C$. panamensis alcoholic extract using the Godin reagent.

On the other hand, marginal presence of terpenes was observed in the aqueous extracts. Saponins were observed in the majority of the extracts. Whilst, yellow spots indicative of flavonoids using ceric sulphate reagent, were observed only in $G$. pulchra and $P$. acimarius ethanol extracts.

\section{Glucose-6-phosphatase activity}

The data are expressed in $\%$ inhibition in order

Table 1. An aqueous and alcohol plant extracts screened and phytochemical analysis.

\begin{tabular}{lccc}
\hline & & \multicolumn{2}{c}{ Phytochemical analysis (detection of antiradical activity) $^{\mathrm{a}, \mathrm{b}}$} \\
\hline Species (Family) & Voucher number & Aqueous extracts & Ethanol extracts \\
\hline Irlbachia alata (Gentianaceae) & $1548 \mathrm{AC}$ & $3,4,5(3)$ & $1,1 \mathrm{~A},(-)$ \\
Tontelea ovalifolia (Hippocrateaceae) & $1373 \mathrm{AC}$ & $1 \mathrm{~A}, 3,5(3,5)$ & $1,1 \mathrm{~A}, 3(3)$ \\
Endlicheria anomala (Lauraceae) & $1282 \mathrm{AC}$ & $3(3)$ & $1,1 \mathrm{~A}(1 \mathrm{~A})$ \\
Gustavia pulchra (Lecythidaceae) & $1306 \mathrm{AC}$ & $1,5(5)$ & $1,1 \mathrm{~A}, 2,3(2,3)$ \\
Phthirusa verruculosa (Loranthaceae) & $1325 \mathrm{AC}$ & $1 \mathrm{~A}, 3,4,5(3,4,5)$ & $1,1 \mathrm{~A}, 3,4(3,4)$ \\
Phthirusa castillana (Loranthaceae) & $1251 \mathrm{AC}$ & $1 \mathrm{~A}, 3,4,5(3,4,5)$ & $1,1 \mathrm{~A}, 3(3)$ \\
Psittacanthus acimarius (Loranthaceae) & $1302 \mathrm{AC}$ & $3,4,5(3,4,5)$ & $1,2,3,4(2,3,4)$ \\
Tetrapterys styloptera (Malpighiaceae) & $1275 \mathrm{AC}$ & $1 \mathrm{~A}, 3,4,5(3,4,5)$ & $1,1 \mathrm{~A}, 3,4(3,4)$ \\
Tetrapterys mucronata (Malpighiaceae) & $1623 \mathrm{AC}$ & $1 \mathrm{~A}, 3(3)$ & $1 \mathrm{~A}(-)$ \\
Calathea panamensis (Maranthaceae) & $1374 \mathrm{AC}$ & $1 \mathrm{~A}, 3(3)$ & $1 \mathrm{~A}, 3,6(3,6)$ \\
Phorandendron piperoides (Viscaceae) & $1385 \mathrm{AC}$ & $\mathrm{ND}$ & $1,1 \mathrm{~A}, 3(3)$ \\
Vismia japurensis (Clusiaceae) & $1295 \mathrm{AC}$ & $3,4,5(3,4,5)$ & $\mathrm{NE}$ \\
\hline
\end{tabular}

${ }^{a}$ 1. Triterpenoid; 1A. Monoterpenoid; 2. Flavonoid (detected by ceric sulphate solution); 3. Alkaloids; 4. Secoiridoids, 5. saponins (detected in the aqueous extracts); 6. Polyphenols (flavonoids, Naphthoquinones or Xanthones). ${ }^{\mathrm{b}}$ The number in parenthesis indicates the type of compound with the antiradical activity and the minus sign indicates no activity. ND: not detected. NE: not evaluated. 
Table 2. Results of glucose-6-phosphatase hydrolysis inhibition for the extracts.

\begin{tabular}{|c|c|c|c|c|c|c|c|c|}
\hline \multirow{3}{*}{ Species (Family) } & \multicolumn{4}{|c|}{ Aqueous extracts ${ }^{\mathrm{a}}$} & \multicolumn{4}{|c|}{ Ethanol extracts ${ }^{\mathrm{a}}$} \\
\hline & \multicolumn{2}{|c|}{ Intact microsomes } & \multicolumn{2}{|c|}{$\begin{array}{l}\text { Disrupted } \\
\text { microsomes }\end{array}$} & \multicolumn{2}{|c|}{ Intact microsomes } & \multicolumn{2}{|c|}{$\begin{array}{l}\text { Disrupted } \\
\text { microsomes }\end{array}$} \\
\hline & Activity & $\%$ & Activity & $\%$ & Activity & $\%$ & Activity & $\%$ \\
\hline $\begin{array}{l}\text { Irlbachia alata } \\
\text { (Gentianaceae) }\end{array}$ & $1.18 \pm 0.20$ & 57.7 & $5.18 \pm 0.90$ & 0 & $1.38 \pm 0.17$ & 61.7 & $11.05 \pm 0.96$ & 1.3 \\
\hline $\begin{array}{l}\text { Tontelea ovalifolia } \\
\text { (Hippocrateaceae) }\end{array}$ & $0.37 \pm 0.09$ & 86.7 & $1.65 \pm 0.32$ & 65.8 & $0.68 \pm 0.02$ & 81.0 & $9.27 \pm 0.80$ & 17.2 \\
\hline $\begin{array}{l}\text { Endlicheria anómala } \\
\text { (Lauraceae) }\end{array}$ & $1.60 \pm 0.05$ & 43.0 & $4.46 \pm 0.50$ & 7.0 & $1.61 \pm 0.08$ & 55.3 & $10.09 \pm 1.19$ & 9.8 \\
\hline $\begin{array}{l}\text { Gustavia pulchra } \\
\text { (Lecythidaceae) }\end{array}$ & $0.67 \pm 0.03$ & 76.0 & $2.94 \pm 0.42$ & 38.7 & $1.01 \pm 0.31$ & 71.9 & $10.88 \pm 1.57$ & 2.8 \\
\hline $\begin{array}{l}\text { Phthirusa verruculosa } \\
\text { (Loranthaceae) }\end{array}$ & $0.25 \pm 0.01$ & 91.2 & $3.01 \pm 0.83$ & 37.7 & $0.30 \pm 0.09$ & 91.6 & $8.83 \pm 0.82$ & 21.1 \\
\hline $\begin{array}{l}\text { Phthirusa castillana } \\
\text { (Loranthaceae) }\end{array}$ & $0.28 \pm 0.01$ & 90.0 & $3.15 \pm 0.31$ & 34.4 & $0.60 \pm 0.04$ & 83.3 & $11.02 \pm 2.94$ & 1.5 \\
\hline $\begin{array}{l}\text { Psittacanthus acimarius } \\
\text { (Loranthaceae) }\end{array}$ & $0.64 \pm 0.03$ & 77.0 & $2.84 \pm 0.40$ & 40.9 & $0.42 \pm 0.05$ & 88.3 & $10.72 \pm 0.80$ & 4.2 \\
\hline $\begin{array}{l}\text { Tetrapterys styloptera } \\
\text { (Malpighiaceae) }\end{array}$ & $0.44 \pm 0.02$ & 84.2 & $3.58 \pm 0.68$ & 25.3 & $0.25 \pm 0.08$ & 93.0 & $7.88 \pm 0.96$ & 29.6 \\
\hline $\begin{array}{l}\text { Tetrapterys mисronata } \\
\text { (Malpighiaceae) }\end{array}$ & $2.12 \pm 0.40$ & 24.0 & $5.85 \pm 0.87$ & 0 & $1.95 \pm 0.23$ & 45.8 & $11.30 \pm 0.86$ & 0 \\
\hline $\begin{array}{l}\text { Calathea panamensis } \\
\text { (Maranthaceae) }\end{array}$ & $2.08 \pm 0.36$ & 25.4 & $4.44 \pm 0.60$ & 8.0 & $1.21 \pm 0.02$ & 66.3 & $10.73 \pm 0.89$ & 4.1 \\
\hline $\begin{array}{l}\text { Phorandendron piperoides } \\
\text { (Viscaceae) }\end{array}$ & $2.58 \pm 0.56$ & 8.0 & $4.19 \pm 0.53$ & 12.6 & $0.46 \pm 0.03$ & 87.3 & $8.39 \pm 0.88$ & 25.0 \\
\hline $\begin{array}{l}\text { Vismia japurensis } \\
\text { (Clusiaceae) }\end{array}$ & $0.28 \pm 0.01$ & 89.9 & $2.37 \pm 0.38$ & 50.6 & $\mathrm{NE}$ & $\mathrm{NE}$ & $\mathrm{NE}$ & NE \\
\hline Control & $2.80 \pm 0.60$ & - & $4.80 \pm 0.40$ & - & $3.60 \pm 0.71$ & - & $11.19 \pm 1.86$ & - \\
\hline Phloridzin ${ }^{\mathrm{b}}$ & $1.14 \pm 0.59$ & 59.2 & $3.39 \pm 0.35$ & 29.4 & $1.55 \pm 0.18$ & 56.9 & $8.07 \pm 0.91$ & 27.9 \\
\hline
\end{tabular}

${ }^{a}$ The assays for aqueous and ethanol extracts were performed in different days. ${ }^{b}$ Used as a positive control, NE: no evaluated.

Table 3. Antiradical activity: $\mathrm{IC}_{50}(\mathrm{ppm})$ and $\operatorname{Kobs}\left(\mathrm{S}^{-1}\right)$ of aqueous and ethanol plant extracts.

\begin{tabular}{|c|c|c|c|c|}
\hline \multirow{2}{*}{ Species (Family) } & \multicolumn{2}{|c|}{$\mathrm{IC}_{50}(\mathrm{ppm})^{\mathrm{A}}$} & \multicolumn{2}{|c|}{$\operatorname{Kobs}\left(\mathrm{s}^{-1}\right)$} \\
\hline & Aqueous extracts & Ethanol extracts & Aqueous extracts & Ethanol extracts \\
\hline Irlbachia alata (Gentianaceae) & 1189.53 & 585.34 & 1.417 & 0.006 \\
\hline Tontelea ovalifolia (Hippocrateaceae) & 750.75 & 548.97 & 1.969 & 0.116 \\
\hline Endlicheria anomala (Lauraceae) & 825.25 & 100.00 & 0.067 & 0.012 \\
\hline Gustavia pulchra (Lecythidaceae) & 1030.50 & 657.47 & 0.352 & 0.067 \\
\hline Phthirusa verruculosa (Loranthaceae) & 250.00 & 164.28 & 0.275 & 0.160 \\
\hline Phthirusa castillana (Loranthaceae) & 674.54 & 147.34 & 0.095 & 0.014 \\
\hline Psittacanthus acimarius (Loranthaceae) & 337.97 & 142.80 & 0.186 & 0.264 \\
\hline Tetrapterys styloptera (Malpighiaceae) & $\mathrm{NE}$ & 153.85 & $\mathrm{NE}$ & 0.037 \\
\hline Tetrapterys mucronata (Malpighiaceae) & 888.31 & 575.51 & 0.271 & 0.008 \\
\hline Calathea panamensis (Maranthaceae) & 757.58 & 586.51 & fast & 0.013 \\
\hline Phorandendron piperoides (Viscaceae) & $\mathrm{NE}$ & 563.25 & NE & 0.160 \\
\hline Vismia japurensis (Guttiferae) & 726.60 & $\mathrm{NE}$ & 0.213 & NE \\
\hline Quercetin & \multicolumn{2}{|c|}{$1.94^{\mathrm{B}}$} & \multicolumn{2}{|c|}{0.748} \\
\hline
\end{tabular}

${ }^{\mathrm{a}}[\mathrm{DPPH}]=23.64 \mathrm{ppm}(60 \mu \mathrm{M}) \cdot{ }^{\mathrm{b}}[$ quercetin $]=82 \mu \mathrm{g} / \mathrm{mg} \mathrm{DPPH},[\mathrm{DPPH}]=60 \mu \mathrm{M} . \mathrm{NE}=$ Not evaluated. The errors in the $\mathrm{IC}_{50} \mathrm{were}$ less than $3 \%$. The errors in the Kobs were calculated based on the fitting parameters of the curves and in all the cases were less than $2 \%$. 
to compare them with the results shown in previous reports (Jiménez et al., 2001). Without exception, all the extracts inhibited, to a greater or lesser degree, microsomal G-6-Pase enzymatic activity, resulting in greater inhibition on intact microsomes than on disrupted ones. Marked effects $(>70 \%)$ were observed for both aqueous and alcoholic extracts of T. ovalifolia, $G$. pulchra, $P$. verruculosa and $P$. castillana, $P$. acimarius, $T$. styloptyera and $V$. japurensis (Table 2). These plants showed presence of alkaloids, secoridoids and saponins (Table 1). It is worth to note that all the extracts mentioned above showed more inhibition than the positive control phloridzin (Table 2).

\section{Antiradical activity}

Each extract was chromatographed on TLC plate in order to evaluate qualitatively radical scavenging ability of the components present in the extracts. The plates were sprayed with DPPH methanol solution and heated. A pale yellow spot against a DPPH purple background is indicative of trapping DPPH radical. The results are presented in Table 1. Spots corresponding to saponin, alkaloid and secoiridoid in the aqueous extracts from $T$. ovalifolia, $P$. acimarius, $P$. verruculosa, $T$. styloptera and $V$. japurensis showed positive yellowish color.

The $\mathrm{IC}_{50}(\mathrm{ppm})$ and Kobs $\left(\mathrm{s}^{-1}\right)$ values of the extracts are shown in Table 3 . The aqueous extracts of $P$. verruculosa, and $P$. acimarius, in which alkaloids, saponins and secoiridoids were detected, showed the best $\mathrm{IC}_{50}$ with 250.0 and 337.97, respectively (Table 3 ). The aqueous extracts of $T$. ovalifolia, E. anomala, T. mucronata, $C$. panamensis, $P$. castillana and $V$. japurensis, showed $\mathrm{IC}_{50}$ values between $600-900 \mathrm{ppm}$ (Table 3). I. alata and G. pulchra, showed weak effects with $\mathrm{IC}_{50}$ values higher than 1000 ppm (Table 3), although in these extracts we detected alkaloids for $I$. alata, and saponins and alkaloids for G. pulchra (Table 1).

All the ethanol extracts tested had an $\mathrm{IC}_{50}$ lower than $700 \mathrm{ppm}$ and were more effective DPPH radical scavengers than corresponding aqueous extracts in all the cases. The best results were obtained with E. anomala, $P$. castillana and $P$. acimarius which showed $\mathrm{IC}_{50}$ of $100,147.34$ and $142.80 \mathrm{ppm}$, respectively, followed by $P$. verruculosa (164.28 ppm) and T. styloptera (153.85 ppm). The other six extracts tested had lower activities with $\mathrm{IC}_{50}$ close to $600 \mathrm{ppm}$.

The phytochemical studies showed the presence of alkaloids and with a minor proportion, secoiridoids in almost all the extracts. Flavonoids were detected only in the ethanol extracts of G. pulchra and P. acimarius. Only mono and triterpenoids were detected in the ethanol extract of E. anomala. For this reason, no assumption can be made about the DPPH scavenger activity with respect to classes of compounds in these extracts. Nerveless, some triterpenoids with the aromatic phenol moiety like cognatin, isolated from Cheiloclinium cognatum, and some phenolic components of essential oils like carvacrol detected in the Thymus genus had showed DPPH scavenger activity (Jeller et al., 2004; Tepe et al., 2005). Only in the ethanol extract of $C$. panamensis non-flavonoid polyphenols were detected.

All the aqueous extracts were found to bleach the DPPH purple color. For I. alata, T. ovalifolia and $C$. panamensis, this bleach was reached in a few seconds, while, for the other species, the bleach was observed in the first five minutes. This scavenging of the DPPH radical could be considered mainly due to the presence of metabolites like essential oils, alkaloids, and polyphenols (Table 1 and 3 ).

The reaction rates observed for E. anomala and $P$. castillana, were slower than the other extracts. This probably means that the compounds containing labile hydrogen in these extracts are in minor proportion. The Kobs, calculated for the alcoholic extracts, are lower than those of the aqueous extracts for the same species, except $P$. acimarius. These results can be related to different concentrations, or more likely different compositions of active principles in both extracts.

\section{DISCUSSION}

Alkaloids and essential oils were detected in almost all the aqueous and alcoholic extracts. Secoiridoids were observed in the Loranthaceae family (Table 1). Saponins were common to eight of the aqueous extracts and triterpenoids were detected in almost all the alcoholic extracts.

Psittacanthus calyculatus has been used in the traditional Mexican medicine as antidiabetic (AndradeCetto and Heinrich, 2005; Barbosa-Filho et al., 2005). Irlbachia alata, has been traditionally used as antimalarial in the French Guiana (Bertani et al., 2005) and one novel phosphatidylcholine, irlbacholine isolated from this specie, has been used as precursor for synthetic analogs with antifungal activity (Lu et al., 1999). Calathea warscewiczii is used by the Panama traditional medicine for several diseases (Gupta et al., 2005). The plant (aerial) infusions of Phoradendron bolleanum and Phoradendron tomentosum have been used in Mexico by its hypoglycaemic effect. A phytochemical study of these species showed the presence of tannins, saponins, flavonoids, coumarins from $P$. bolleanum and phoratoxins from Phoradendron tomentosum (AndradeCetto and Heinrich, 2005). Tetrapterys styloptera and Phthirusa retroflexa have been investigated for its anti-Mycobacterium tuberculosis activity (Rojas et al., 2003).

No phytochemical and biological reports from Vismia japurensis have been made. Nevertheless, 5dihydroxy-8-methoxyxanthone has been isolated from Vismia amazonica and the plant has been tested for 
antimutagenic activity (Sangwan et al., 1998).

Alkaloids were detected in almost all the extracts studied (Table 1). Those compounds are known to exhibit a variety of biological activities including inhibition of malignant cell growth and proliferation, leishmanicidal, anti-HIV, anti-inflammatory and antioxidant activities (Bacher et al., 2001; Chan-Bacab and Peña-Rodríguez, 2001; Račková et al., 2004; Singh et al., 2005; Barbosa-Filho et al., 2006; Castilhos et al., 2007). On the other hand, secoiridoids are reported to show leishmanicidal and antioxidant activity (ChanBacab and Peña-Rodríguez, 2001; Carrasco-Pancorbo et al., 2005). Triterpenoids and their glycosides (saponins) display a variety of biological activities such as immunomodulatory and antitumoral activity (Plohmann et al., 1997; Fulda et al., 1999). Polyphenols like flavonoids and catechins have been shown to exert a broad spectrum of anti-HIV, leishmanicidal and antioxidant activity (Plumb et al., 1998; Yokozawa et al., 1998; Chan-Bacab and Peña-Rodríguez, 2001; Singh et al., 2005).

We have studied several plants belonging to the Amazonian region trying to seek a relationship between the inhibition of the G-6-Pase activity and the antiradical activity. These plants cited in Table 1 , have not been reported previously concerning G-6-Pase enzymatic activity and DPPH antiradical activity.

G-6-Pase is the enzyme that catalyses the last step of neoglucogenesis and glycogenolysis, and its structure has been elucidated as five polypeptide subunits (Burchell and Waddell, 1991). Its inhibition might be of some help in the control of the hyperglycaemia present in the diabetes. A relationship between inhibitory effects of the G-6-Pase activity and the presence of some metabolites like alkaloids, saponins, secoiridoids and polyphenols was observed for the evaluated extracts (Tables 1 and 2 ). In general, the extracts were much more effective on intact microsomes than on disrupted ones. This fact means that the extract causes an inhibitory action mainly on the G-6-P transporter ( $\mathrm{T} 1$ transporter) but also on the G-6-Pase catalytic subunit. It is also possible that the extracts affect the flow-out of phosphate ion and/or glucose and the products of G-6-P hydrolysis in microsomes (T2 and/ or T3 transporter), (Van Schaftingen and Gerin, 2002). Three species belonging to the Loranthaceae family were notably effective as well as $V$.japurensis, T. ovalifolia and T. styloptera. The ethanol extracts result more effective than the aqueous ones with inhibition percentages between $60-95 \%$ for nine of the evaluated extracts.

Based on the mechanism of the DPPH reduction, and on previous studies of the antioxidant plants (unpublished results), it is possible to propose that the antioxidant activity could be due, at least in part, to the presence of metabolites with a labile hydrogen like phenolic compounds (e.g. flavonoids, coumarins, naphthoquinones, tannins, etc.) and nitrogen-containing compounds (alkaloids).

The results about the antiradical activity displayed by the ethanol extract of E. anomala are very singular. Its alcoholic extract is rich in compounds like terpenoids (essential oils and triterpenoids); Nerveless, the best antiradical activity was observed. Monoterpenoids like carvone possess high antioxidant activity (Elmastas et al., 2006; Souza et al., 2007) and some components of essential oils from Artemisia species have been showed antioxidant activity (Kordali et al., 2005).

The results from the Loranthaceae family are interesting; a relationship between the phytochemical constitution, the G-6-Pase inhibition activity and the antiradical activity $\left(\mathrm{IC}_{50}\right.$ and Kobs) was observed for this family in both extracts. In fact, this family conformed by $P$. verruculosa, $P$. castillana and $P$. acimarius, rich in alkaloids, secoiridoids and flavonoids ( $P$. acimarius $)$, showed high G-6-Pase inhibition and significant antiradical activity. Another interesting alkaloidcontaining plant with presence of high antidiabetic and antioxidant activities was $T$. styloptera of Malpighiaceae family. These results suggest that the species of the Loranthaceae family are possible targets for further test as antidiabetic and antioxidant plants.

\section{ACKNOWLEDGMENTS}

This work was supported by grants 03-12-53262003; 09-4788-05; 09-4706-05 from the Consejo de Desarrollo Científico y Humanístico, Universidad Central de Venezuela and S195001697; S12002000284 from FONACIT.

\section{REFERENCES}

Andrade CA, Costa CK, Bora K, Miguel MD, Miguel OG, Kerber VA 2007. Determinação do conteúdo fenólico e avaliação da atividade antioxidante de Acacia podalyriifolia A. Cunn. ex G. Don, Leguminosaemimosoideae. Rev Bras Farmacogn 17: 231-235.

Andrade-Cetto A, Heinrich M 2005.Mexican plants with hypoglycaemic effect used in the treatment of diabetes. J Ethnopharmacol 99: 325-348.

Bacher G, Beckers T, Emig P, Klenner T, Kutscher B, Nickel B 2001. New small-molecule tubulin inhibitors. Pure Appl Chem 73: 1459-1464.

Barbosa-Filho JM, Vasconcelos THC, Alencar AA, Batista LM, Oliveira RAG, Guedes DN, Falcão HS, Moura MD, Diniz MFFM, Modesto-Filho J 2005. Plants and their active constituents from South, Central, and North America with hypoglycemic activity. Rev Bras Farmacogn 15: 392-413.

Barbosa-Filho JM, Piuvezam MR, Moura MD, Silva MS, Lima KVB, Cunha EVL, Fechine IM, Takemura OS 2006. Anti-inflammatory activity of alkaloids: A twentycentury review. Rev Bras Farmacogn 16: 109-139.

Bertani S, Bourdy G, Landau I, Robinson J, Esterre P, Deharo E 2005. Evaluation of French Guiana traditional antimalarial remedies. $J$ Ethnopharmacol 98: 45-54. 
Bilia AR, Ciampi L, Méndez J, Morelli I 1996. Phytochemical investigations of Licania genus. Flavonoids from Licania pyrifolia. Pharm Acta Helv 71: 199-204.

Boynes J 1991. Role of oxidative stress in development of complications in diabetes. Diabetes 40: 405-412.

Burchell A, Hume R, Burchell B 1988. A new microtechnique for the analysis of the human hepatic microsomal glucose-6-phosphatase system. Clin Chim Acta 173: 183-192.

Burchell A, Waddell ID 1991. The molecular basis of the hepatic microsomal glucose-6-phosphatase system. Biochim Biophys Acta 1092: 129-137.

Carrasco-Pancorbo A, Cerretani L, Bendini A, SeguraCarretero A, Del Carlo M, Gallina-Toschi T, Lercker G, Compagnone D, Fernández-Gutiérrez A 2005. Evaluation of the antioxidant capacity of individual phenolic compounds in virgin olive oil. J Agric Food Chem 53: 8918-8925.

Castilhos TS, Giordani RB, Henriques AT, Menezes FS, Zuanazzi JAS 2007. Avaliação in vitro das atividades antiinflamatória, antioxidante e antimicrobiana do alcalóide montanina. Rev Bras Farmacogn 17: 209214.

Chan-Bacab MJ, Peña-Rodríguez LM 2001. Plant natural products with leishmanicidal activiy. Nat Prod Rep 18: 674-688

Collier A, Wilson R, Bradley H, Thomson JA, Small M 1990. Free radical activity in type 2 diabetes. Diabet Med 7: 27-30

Cuendet M, Hostettmann K, Potterat O, Dyatmiko W 1997. Iridoid glucosides with free radical scavenging properties from Fagraea blumei. Helv Chim Acta 80: 1144-1152.

Delazar A, Talischi B, Nazemiyeh H, Rezazadeh H, Nahar L, S.D. Sarker SD 2006. Chrozophorin: a new acylated flavone glucoside from Chrozophora tinctoria (Euphorbiaceae). Rev Bras Farmacogn 16: 286290.

Elmastas M, Dermistas I, Isidak O, Aboul-Enein H 2006. Antioxidant activity of S-carvone isolated from spearmint (Mentha spicata L. Fam Lamiaceae). J Liq Chromatogr Related Technol 29: 1465-1475.

Finkel T, Holbrook NJ 2000. Oxidants, oxidative stress and the biology of ageing. Nature 408: 239-247.

Fulda S, Jeremias I, Steiner HH, Pietsch T, Debatin K-M 1999. Betulinic acid: a new cytotoxic agent against malignan brain-tumor cells. Inter J Cancer 82: 435441.

Gupta MP, Solis PN, Calderon AI, Guionneau-Sinclair F, Correa M, Galdames C, Guerra C, Espinosa A, Alvenda GI, Robles G, Ocampo R 2005. Medical ethnobotany of the Teribes of Bocas del toro Panáma. J Ethnopharmacol 96: 389-401.

Halliwell B 1994. Free radical, antioxidants and human disease: Curiosity, cause or consequence. Lancet 344: 721-724.

Jeller AH, Siqueira DE, Morais L, da Silva V, Furlan M 2004. Antioxidant phenolic and quinonemethide triterpenes from Cheiloclinium cognatum. Phytochemistry 65: 1977-1982.

Jiménez G, Hasegawa M, Rodríguez M, Estrada O, Méndez J, Castillo A, González-Mújica F, Motta N, Vásquez J, Romero-Vecchione E 2001. Biological screening of plants of the Venezuelan Amazons. $J$ Ethnopharmacol 77: 77-83.

Koleva II, van Beek TA, Linssen JP, de Groot A, Evstatieva LN 2001. Screening of plant extracts for antioxidant activity: a comparative study on three testing methods. Phytochem Anal 13: 8-17.

Kordali S, Cakir A, Mavi A, Kilic H, Yildirim A 2005. Screening of chemical composition and antifungal and antioxidant activities of the essential oils from three Turkish Artemisia species. J Agric Food Chem 53: 1408-1416.

Larson RA 1988. The antioxidants of higher plants. Phytochemistry 27: 969-978.

Lu Q, Ubillas RP, Zhou Y, Dubenko LG, Dener JM, Litvak J, Phuan P-W, Flores M, Ye ZJ, Gerber RE, Truong T, Bierer DE 1999. Synthetic analogues of irlbacholine: A novel antifungal plant metabolite isolated from Irlbachia alata. J Nat Prod 62: 824-828.

Marcucci OL, González-Mujica F, Perez-Ayuso E 1983. Alterations of liver nuclear envelopes accompanying thioacetamide administration in rats. Acta Cient Venez 34: 109-117.

Markwell M, Hass S, Bieber L, Tolbert N 1978. A modification of the Lowry procedure to simplify protein determination in membrane and lipoprotein sample. Anal Biochem 87: 206-210.

Mc Cune L, Johns T 2002. Antioxidant activity in medicinal plants associated with the symptoms of diabetes mellitus used by the Indigenous Peoples of the North American boreal forest. J Ethnopharmacol 82: 197205.

Naik GH, Priyadarsini KI, Naik DB, Gangabhagirathi R, Mohan H 2004. Studies on the aqueous extract of Terminalia chebula as a potent antioxidant and a probable radioprotector. Phytomedicine 11: 530538.

Naik GH, Priyadarsini KI, Mohan H 2006. Free radical scavenging reactions and phytochemical analysis of Triphala, an ayurvedic formulation. Curr Sci 90: 1100-1105.

Plohmann B, Bader G, Hiller K, Franz G 1997. Immunomodulatory and antitumoral effects of triterpenoid saponins. Pharmazie 52: 953-957.

Plumb GW, De Pascual-Teresa S, Santos-Buelga C, Cheynier V, Williamson G 1998. Antioxidant properties of catechins and proanthocyanidins: Effect of polymerisation, galloylation and glycosylation. Free Radical Res 29: 351-358.

Račková L, Májeková M, Košt'álová D, Štefek M 2004. Antiradical and antoxidant activities of alkaloids isolated from Mahonia aquifolium. Structural aspects. Bioorg Med Chem 12: 4709-4715.

Rocha FD, Pereira RC, Kaplan MAC, Teixeira VL 2007. Produtos naturais de algas marinhas e seu potencial antioxidante. Rev Bras Farmacogn 17: 631-639.

Rojas R, Bustamante B, Fernández I, Albán J, Lock O 2003. Antimicrobial activity of Peruvian medicinal plants. J Ethnopharmacol 88: 199-204.

Sabu MC, Kuttan R 2002. Anti-diabetic activity of medicinal plants and its relationship with their antioxidant property. J Ethnopharmacol 81: 155-160.

Sangwan NS, Shanker S, Sangwan RS, Kumar S 1998. Plantderived products as antimutagens. Phytother Res 12: 
389-399.

Silva CG, Herdeiro RS, Mathias CJ, Panek AD, Silveira CS, Rodrigues VP, Rennó MN, Falcão DQ, Cerqueira DM, Minto ABM, Nogueira FLP, Quaresma CH, Silva JFM, Menezes FS, Eleuterio ECA 2005. Evaluation of antioxidant activity of Brazilian plants. Pharmacol Res 52: 229-233.

Singh IP, Bharate SB, Bhutani KK 2005. Anti-HIV natural products. Curr Sci 89: 269-290.

Souza TJT, Apel MA, Bordignon S, Matzenbacher NI, Zuanazzi JAS, Henriques AT 2007. Composição química e atividade antioxidante do óleo volátil de Eupatorium polystachyum DC. Rev Bras Farmacogn 17: 368-372.

Stahl E 1969. Thin layer chromatography. $2^{\text {nd }}$ edition. SpringerVerlag, New York.

Tepe B, Sokmen M, Akpulat HA, Daferera D, Polissiou M, Sokmen A 2005. Antioxidative activity of the essential oils of Thymus sipyleus subsp. spyleus var. sipyleus and Thymus sipyleus subsp. spyleus var. rosulans. J Food Eng 66: 447-454.

Tiwari AK, Rao JM 2002. Diabetes mellitus and multiple therapeutic approaches of phytochemicals: Present status and future prospects. Curr Sci 83: 30-38.

Van Shaftingen E, Gerin I 2002. The glucose-6-phosphatase system. Biochem J 362: 513-532.

Vicentino ARR, Menezes FS 2007. Atividade antioxidante de tinturas vegetais, vendidas em farmácias com manipulação e indicadas para diversos tipos de doenças pela metodologia do DPPH. Rev Bras Farmacogn 17: 384-387.

Wagner H, Bladt S, Zgainski EM 1984. Plant drug analysis. $A$ thin layer Chromatography Atlas. Springer-Verlag, Berlin.

Westergaard N, Madsen P 2001. Glucose-6-phosphatase inhibitors for the treatment of type 2 diabetes. Expert Opin Ther Pat 11: 1429-1441.

Yokozawa T, Chen CP, Dong E, Tanaka T, Nonaka GI, Nishioka I 1998. Study on the inhibitory effect of tannins and flavonoids against the 1,1-diphenyl-2-picrylhydrazyl radical. Biochem Pharmacol 56: 213-222. 